\title{
Anne Kaygı Düzeyinin Ergen Kaygı Düzeyi Üzerindeki Etkisinde Ergenin Bilinçli Farkındalık Düzeyinin Aracı Etkisi ${ }^{1}$
}

\section{The Mediator Effect of Mindfulness Level Adolescent on The Effect of Maternal Anxiety Level on The Adolescent Anxiety Level}

\author{
Hayat Boğday ${ }^{1}$, Z. Deniz Aktan², Eda Yardımci ${ }^{3 *}$ \\ ${ }^{1}$ Klinik Psikolog, hayatbogday@gmail.com, 0000000320025355 \\ ${ }^{2}$ Dr. Klinik Psikolog, Işı1k Üniversitesi, deniz.aktan@isıkun.edu.tr, 0000000317572024 \\ ${ }^{3}$ Klinik Psikolog, Işık Üniversitesi, edayardimci@gmail.com, 0000000206459563 * Sorumlu Yazar
}

Geliş tarihi/Received:11.02.2021

Kabul tarihi/Accepted:24.06.2021

Yayın tarihi/Published:30.06.2021

\section{ÖZET}

$\mathrm{Bu}$ çalışmanın amacı, anne kaygı düzeyi ile ergen kaygı düzeyi arasındaki ilişkinin, aracı değişkenimiz olan ergen bilinçli farkındalık düzeyinden ne derece etkilendiğini analiz etmektir. 276 anne ve ergen katılımcının bulunduğu bu çalışmanın örneklemini, İstanbul ili sınırları içerisinde yer alan 14-17 yaş aralığındaki ergenler ve anneleri oluşturmaktadır. Katılımcıların kaygı düzeylerini değerlendirmek adına Durumluk-Sürekli Kaygı Envanteri, ergenlerin bilinçli farkındalık düzeylerini değerlendirmek adına Bilinçli Farkındalık Ölçeği (BİFÖ) ve ergenlere uygulanan bu ölçeklerin aileye dair sosyodemografik değişkenlerden etkilenme durumunu değerlendirmek adına ise sosyodemografik bilgi formu kullanılmıştır. Anne kaygı düzeyi (durumluk ve sürekli), ergen kaygı düzeyi (durumluk ve sürekli) ve ergen bilinçli farkındalık düzeyi arasındaki korelatif ilişkilerin anlamlı olmasından dolayı aracı etki analizi gerçekleştirilmiştir. Yapılan analiz sonucunda, anne durumluk kaygı düzeyinin ergen kaygı düzeyi (durumluk ve sürekli) üzerindeki etkisinin anlamlı olduğu bulunmakla birlikte söz konusu ilişkide bilinçli farkındalığın kısmi aracı etkiye sahip olduğu saptanmıştır. Son olarak, anne sürekli kaygı düzeyinin ergen kaygı düzeyi (durumluk ve sürekli) üzerindeki etkisinin anlamlı olduğu bulunmakla birlikte söz konusu ilişkide bilinçli farkındalığın tam aracı etkiye sahip olduğu saptanmıştır. Çalışmadan elde edilen sonuçlar ışığında anne kaygı düzeyi ve ergen kaygı düzeyi arasındaki ilişkide bilinçli farkındalığın aracı etkisinin olduğu saptanmıştır.

Anahtar Kelimeler: Durumluk kaygı, sürekli kaygı, bilinçli farkındalık, ergen, anne

\begin{abstract}
This study aims to analyze the mediator effect of mindfulness levels of adolescent on the relationship between maternal and child anxiety symptoms. The present study consists of participants with 276 adolescents aged between 14-17 years old and their mothers who live in İstanbul. The State-Trait Anxiety Inventory (STAI) and the Mindfulness Attention Awareness Scale (MAAS), were used to evaluate the anxiety levels of the participants and the mindfulness levels of the adolescents respectively. At the same time, the sociodemographic information form was used to find out how these scales applied to the adolescents who are affected by the socio-demographic variables regarding the family. Mediator effect analysis was performed as it was found out according to the research findings that the correlation between maternal anxiety level (state and trait), adolescent anxiety level (state and trait) and adolescent mindfulness level are statistically significant. As a result of the analysis, the effect of maternal state anxiety level on adolescent anxiety level (state and trait) was significant. But it was found that the mediating effect of mindfulness in this relationship was partially significant. In conclusion, the effect of maternal trait anxiety level on adolescent anxiety level (state and trait) was significant and mindfulness was found to have a full mediating effect in this relationship. The results obtained from the study showed that mindfullness has mediating effect on the relationship between maternal anxiety level and adolescent anxiety level.
\end{abstract}

Keywords: State anxiety, trait anxiety, mindfulness, adolescent, mother

\footnotetext{
${ }^{1}$ Bu makale birinci yazarın Işık Üniversitesi Sosyal Bilimler Enstitüsü Psikoloji Ana Bilim Dalı’nda savunduğu "Anne kaygı düzeyinin ergen kaygı düzeyi üzerindeki etkisinde ergenin bilinçli farkındalık düzeyinin aracı etkisi" isimli yüksek lisans tezinden türetilmiştir.
} 


\section{Gíriş}

İnsan doğası gereği sosyal yaşamın bir parçasıdır ve ilişsiler içinde büyüyüp, gelişir. Bu ilişkiler içinde anneyle olan ilişki, insan hayatında çok önemli bir yer kaplamaktadır. Çocuğun doğumundan sonra yaşadığı ilk ilişkinin anne ile olduğu düşünüldüğünde, annenin ergenlik dönemindeki biyopsikososyal gelişimdeki rolü daha anlaş1lır hale gelmektedir. Nitekim çocuk, bağımsız bir birey haline gelene kadar anne babasıyla olan ilişkileri psikolojik gelişiminde önemli yansımalara sahiptir. Bu nedenle, bireyin fiziksel, bilişsel, sosyal açıdan değişim geçirdiği ergenlik döneminde ailesiyle kurduğu ilişkinin niteliği sağlıklı bir benlik oluşturması üzerinde etkilidir ve bireyin gelecekteki hayatını şekillendiren etkiler yaratabilmektedir (Kırık, 2014).

Anne ile olan ilişki içinde büyür ve gelişirken güzel zamanların yanında zorluklar da yaşanır ve bu zorluklarla baş ederken çoğu zaman kaygı bireye eşlik eder. Kaygı genellikle hoşa gitmeyen veya acı verici bir his uyandırsa da kişinin varoluşu için gerekli, yaşamsal bir güçtür (Ulutaş ve Demiriz, 2003). Rahatsız edici bir his uyandıran kaygı, aslında çocuğun normal gelişiminin bir parçasıdır. Çocuk, gelişimiyle beraber anneden ayrılma kaygısı, başarı kaygısı, sosyalleşme kaygısı gibi birçok konuda kaygı hissetmektedir (Ulutaş ve Alisinanoğlu, 2003). Yaşanan bu kaygılar ergenlik döneminde de devam etmektedir. Ergenlik dönemi gelişimsel olarak sıklıkla duygusal dalgalanmaların, çökkün duygu durumların yaşanmasına yol açar. Bu bağlamda değerlendirildiğinde kaygı, ergenlik döneminde en sık karşılaşılan duygulardan biridir (Tahiroğlu, Avc1, Çekin, 2008). Fakat kaygı, günlük yaşamda karşılaşılan farklı durumlar dışında da sık sık yaşanıyorsa patolojik olarak değerlendirilebilir (Messer, Beidel, 1994).

Bir duygu olarak kaygı bulaşıcı özelliğe sahip olduğu için, ergenin çevresinde kaygılı insanların yer alması (anne gibi) bu durumun çocuk tarafından algılanıp özdeşim kurmasıyla gelişebilmektedir. Kaygı yaşayan birey aile üyelerinden biri olmasa bile o bireyle çok vakit geçirdiğimizde kaygı düzeyimiz bu durumdan etkilenebilirken, kaygılı bir annenin çocuğunun da kaygı yaşaması beklediğimiz bir durum olmaktadır (Çifter, 1985; Geçtan, 1995). Yani çocukların kaygı düzeyi çocuğun gelişim sürecinde çevresinde bulunduğu koşullara ve ailesiyle, öğretmenleriyle, arkadaşlarıyla olan ilişkilerine göre şekillenir (Hudson, Dodd, Bovopoulos, 2011).

Günümüzde yapılan araştırmalarda da anksiyöz yapıya sahip annedeki anksiyete düzeyi ile çocuktaki anksiyete düzeyinin benzerlik gösterdiği, kaygının çocuğa bir şekilde bulaştığı ve çocuğun çevresindeki bireyleri örnek aldığı belirtilmektedir (Tükel, 2000). Bu sebeple, anne ve çocuklarının kaygı düzeyleri arasındaki ilişkiye etki eden etmenlerin araştırılmasının gerekli olduğu düşünülmektedir.

Son yıllarda Batı'da, Doğu psikolojisine merakın artması ile Budizm temelli uygulamaların klinik ortamda etkililiğinin araştırılmasına dair çalışmaların da arttığı görülmektedir (Didonna, 2009). Temelini Doğu meditasyon geleneğinden alan bilinçli farkındalık, Budizm temelli psikolojinin kalbi olarak anılır ve özünü oluştur. Bireyin yargılama yapmadan dikkatini sadece şu ana odaklaması ve kabullenmesi, mevcut duygularına, düşüncelerine, algılarına yönelmesi ve deneyimlerinin farkına varması olarak tanımlanan "Bilinçli Farkındalık" ve buna dair uygulamaların insanın yaşamına pek çok olumlu etkisi olduğu bilinmektedir (Kabat-Zinn, Lipworth, Burney, 1985). Günlük hayatlarında bir problemle karşılaşan ve kaygı duyan ergenlerin bu duygularla baş etme yolları değişkenlik göstermektedir. Fakat bu yolları denerken önemli olan etkenlerden biri de kişilerin farkındalık düzeyidir. Örneğin; duygusal çalkantıların yoğun yaşandığ ergenlik döneminde kişi, çeşitli olaylar karşısında veya benlik sorunları 
karşısında endişe, öfke duyabilir. Bireyin, o duygu karşısında "Neden böyle hissediyorum? Yetersizim/ güçsüzüm" duygu ve düşünceleri yerine duruma kendisini yargılamadan, duygusunu kabullenerek yaklaşması bu duygu ve düşünceleri çok daha yönetilebilir kılmaktadır. Kişinin duygusunu kabullenmediği, kendi duygusuna yönelik olumsuz yargılarda bulunduğu durumlarda 1stırabın arttığı gözlenmektedir. Bilinçli farkındalık böyle bir durumda kişiye farklı bir yol sunmaktadır (Arslan, 2018).

Literatüre bakıldığında, bilinçli farkındalık kavramıyla ilgili çalışmaların çok uzun zamandır var olmaması sebebiyle bu kavramla ilgili az sayıda bilimsel makalenin bulunduğu görülmektedir. $\mathrm{Bu}$ yüzden bilinçli farkındalık kavramının özellikle 14-17 yaş aralığındaki ergenlerde araştırılması literatüre sağladığı katkı açısından önem arz etmektedir. Türkçe literatüre bakıldığında, çocuğun kaygısının annenin kaygısıyla ilişkilendirildiği çalışmalar, (Geçtan, 1995; Çifter, 1985; Yavuzer, 1994; Ulutaş ve Alisinanoğlu, 2003) bilinçli farkındalık düzeyinin kaygı düzeyini azalttığına dair çalışmalar (Ülev, 2014; Kocaefe, 2013), yabancı literatürde ise bilinçli farkındalık temelli uygulamaların kaygıyı azalttığına dair çalışmalar (Mercer, Finucane, Stewart, 2006; Kabat-Zinn ve ark., 1985; Semple, Lee, Rosa, 2009; Roemer Lee, Salters-Pedneault, Erisman, Orsillo, Mennin, 2009; Shapiro, Schwartz, Bonner, 1998; Vollestad, Nielsen, Nielsen, 2012) bulunmaktadır. Fakat 14-17 yaş aralığındaki ergenleri kapsayan, ergenler ve annelerinin kaygı düzeyi arasındaki ilişkide ergenin bilinçli farkındalık düzeyinin aracı etkisini inceleyen araştırmalar sınırlıdır.

Tüm bu bilgiler ışı̆̆ında bu çalışmada ergenin anneden görerek öğrendiği/geliştirdiği kaygı düzeyinin, aracı değişkenimiz olan ergenin bilinçli farkındalık düzeyinden ne derece etkilendiğini araştırmak amaçlanmıştır. Buradan hareketle annenin kaygı düzeyi ile ergenin kaygı düzeyi arasındaki ilişkide ergenlik dönemindeki bilinçli farkındalık düzeyinin anlamlı bir aracı etkiye sahip olması beklenmektedir. Böylelikle anneler ve ergenlerin kaygı düzeyleri arasındaki ilişkide, ergenlerin bilinçli farkındalık düzeyinin nasıl bir rol oynadığı anlaşılarak, ergenlerde bilinçli farkındalık temelli uygulamalar için bir kaynak oluşturulabilir. Elde edilen bulguların, günümüzde pek çok insanı büyük oranda etkileyen "kaygı" ve sebep olduğu fiziksel/psikolojik rahatsızlıklara yönelik tedavilerde bilinçli farkındalığın arttırılmasına katkıda bulunması beklenmektedir.

\section{Araştırma Modeli}

\section{YÖNTEM}

Çalışmanın araştırma deseni ilişkisel modelde kesitsel tarama yöntemidir.

\section{Çalışma Grubu}

Bu araştırmanın örneklemini, İstanbul'un Avrupa Yakasında bulunan üç devlet Anadolu lisesi ve iki özel Anadolu lisesi olmak üzere toplam 5 lisede öğrenim gören öğrenciler oluşturmaktadır. 276 anne ve ergen katılımcının bulunduğu çalışma örneklemi 14-17 yaş aralığındaki ergenler ve annelerinden oluşturmaktadır. Terapi görmek ve psikiyatrik bir ilaç kullanmak araştırmanın dışlama kriterleridir. Örneklem olarak ise seçkisiz olmayan uygun örnekleme yöntemi kullanılmıştır. 


\section{Veri Toplama Araçları}

\section{Sosyodemografik Bilgi Formu}

Sosyodemografik verileri içeren bu form, araştırmayı yürüten kişi tarafından oluşturulmuş olup, katılımcılardan alınan demografik bilgilerin araştırmanın olası bulguları üzerindeki etkisini ortaya çıkarmak amacıyla uygulanmıştır. Ergen katılımcılara uygulanan bu form içinde sırasıyla; ergenin cinsiyeti, yaşı, sınıfı, okulu, anne ve babalarının sağ olup olmadığı, ailelerin öğrenim ve toplam gelir düzeyleri, anne-babanın birliktelik durumu, ayrı ise kiminle yaşadığı, kardeş sayısı, kaçıncı çocuk olduğu, okul başarısı, anne ile günde ortalama geçirdiği vakit, annenin kaygı düzeyi, ergenin kendi kaygı düzeyi, günlük yaşamda dikkati "şu anki" deneyimlere odaklama sıklığı, daha önce psikolojik desteğe ihtiyaç duymuş olma durumu, ergendeki psikiyatrik ilaç kullanımı ve tedavi/ terapi süreçleri sorgulanmıştır.

\section{Spielger'in Durumluk- Sürekli Kaygı Envanteri}

Ölçek, Spielger ve arkadaşları tarafından kişilerin sürekli ve durumluk kaygı seviyelerinin ölçülmesi amacıyla 1964 yılında geliştirilmiştir (Spielger, Gorsuch, Lushene, 1964). Öner ve Le Compte (1983) tarafından Türkçeye uyarlanan ölçek, 14 yaş ve üstündeki gençler ve yetişkinler için kullanılmaktadır. Ölçek, toplamda 40 madde olmak üzere, kısa cümlelerden oluşan ve bireyin kendini değerlendirdiği bir yapıdadır. "Durumluk Kaygı Ölçeği”" 20 maddelik bir ölçek olmak üzere bireyin sadece o anda hissettikleri hakkında bilgi verirken, yine 20 maddeden oluşan "Sürekli Kaygı Formu" bireyin son yedi gün içinde hissettiklerini değerlendirmektedir. Sürekli kayg1 formu 1-4 arası derecelendirilen likert türünde bir envanterdir. Durumluk Kaygı ölçeğinin cevaplanmasında; maddelerin belirttiği durumların şiddet derecesine göre "hiç", "biraz", "çok" ve tamamıyla" seçeneklerinden birinin tercih edilmesi. Sürekli Kaygı ölçeğinin yanıtlanmasında ise maddelerde ifade edilen durumların sıklık derecesine göre "hemen hiçbir zaman", "bazen", "çok zaman" ve "hemen her zaman" seçeneklerinden birinin tercih edilmesi istenir (Öner ve Le Compte, 1983).

Ölçekler, (1) doğrudan ya da düz (direct) ve (2) tersine dönmüş (reverse) olmak üzere iki şekilde ifade içerir. Negatif duygular doğrudan ifadelerde yer alırken; pozitif duygular ise tersine dönmüş ifadeler içinde yer alır. Durumluk kaygı ölçeğinde on tane tersine dönmüş madde bulunur ve bunlar 1., 2., 5., 8., 10., 11., 15., 16., 19. ve 20. maddelerdir. Sürekli kayg1 envanterinde ise yedi tane tersine kodlanmış madde bulunur ve bunlar 21., 26., 27., 30., 33., 36. ve 39. maddelerdir. Normal ve hasta örneklemleriyle yapılmış olan güvenilirlik çalışması sonucunda Alpha güvenirliğinin .83 ile .87 arasında, test-tekrar test güvenirliğinin .71 ile .86 arasında ve madde güvenirliğinin .34 ile .72 arasında değiştiği saptanmıştır (Öner ve Le Compte,1983; Aydemir ve Köroğlu, 2000; Özusta, 1995). Araştırma örneklemi ile yapılan güvenirlik analizinde annelere uygulanan durumluk kaygı alt boyutunun Cronbach Alpha değeri .60 olarak bulunurken, annelere uygulanan sürekli kayg1 alt boyutunun Cronbach Alpha

değeri .80 olarak bulunmuştur. Ergenlere uygulanan durumluk kayg1 alt boyutuna yapılan güvenirlik analizi sonucunda Cronbach Alpha değeri .59 olarak bulunurken, ergenlere uygulanan sürekli kaygı alt boyutuna yapılan güvenilirlik analizi sonucunda Cronbach Alpha değeri .60 olarak bulunmuştur.

\section{Bilinçli Farkındalık Ölçeği (BİFÖ)}

Bilinçli Farkındalık Ölçeği (BİFÖ), bireylerin bilinçli farkındalık düzeyini değerlendirmek amacıyla 2003 yılında Brown ve Ryan tarafından geliştirilmiştir. Bilinçli Farkındalık Ölçeği (BİFÖ), 15 maddeden oluşan günlük yaşamda o anda yaşananların farkında olma ve bu anlara 
odaklanma yönündeki genel yaklaşımı değerlendiren bir envanterdir. Tek faktörlü bir yapıyı içeren bu ölçek aynı zamanda tek bir toplam puan verir. Ölçekten elde edilen puanlar yükseldikçe bilinçli farkındalık düzeyi de yükselmektedir. BİFÖ 1-6 arasında derecelenen (hemen hemen her zaman, çoğu zaman, bazen, nadiren, oldukça seyrek, hemen hemen hiçbir zaman) likert türünde bir envanterdir. Bögels tarafından 2011 yılında, 11-17 yaş aralığında bulunan ergenlere uygulayabilmek amacıyla geçerlik güvenirlik çalışması yapılmıştır. $\mathrm{Bu}$ çalışma sonucu, ölçeğin iç tutarlılık kat sayısı, .86 bulunmuştur. BİFÖ'de yer alan maddelerin toplam korelasyonları .34 ile .65 arasında değişim göstermektedir. Ölçeğin maddelerden her biri için madde faktör yüklerinin kolaylıkla .30 kritik değerini geçtiği bulunmuştur (Bögels, 2011). Ölçek, Türkçeye 2019 yılında Yavuz tarafından uyarlanmış ve 14-17 yaş aralığındaki öğrenciler üzerinde, ölçeğin geçerlik güvenirlik çalışması yapılmıştır. BİFÖ'nün Cronbach Alpha iç tutarlılık katsayısı .80 ve test-tekrar test korelasyon .60 olarak bulunmuştur (Yavuz ve ark., 2009). Araştırma örneklemi ile yapılan güvenirlik analizinde elde edilen sonuçta ise Cronbach Alpha değeri .81 olarak bulunmuştur.

\section{Verilerin Toplanması}

Çalışma FMV Işık Üniversitesi Sosyal Bilimler Enstitüsü Klinik Psikoloji Yüksek Lisans Programı Alt Etik Kurul Komisyonundan onay alınarak 02.09.2019 tarihinde başlatılmış 2020 Nisan ayında sonlandırılmıştır. Araştırmanın veri toplama adımında, gereken izinlerin ve benzer sosyoekonomik şartların oluşturulması adına, çalışmanın İstanbul ili Kâğıthane ve Beşiktaş ilçelerine bağlı devlet ve özel okullarda uygulanması uygun bulunmuştur. Araştırmayı uygulamaya başlamadan önce Işık Üniversitesi Sosyal Bilimler Enstitüsü etik kurulundan gerekli izinler alınmıştır. İlk olarak annelere öğrenciler aracılığıyla çalışmanın adı, içeriği, hangi amaçla yapıldığına dair açıklayıcı bilgilendirilmiş onam formu ve "Durumluk Sürekli Kaygı" ölçeği gönderilmiştir. Bilgilendirilmiş onam formunu onaylayan anneler aynı zamanda Durumluk Sürekli Kaygı ölçeğini uygulamıştır. Daha sonra ebeveynleri onay veren lise öğrencilerine de ölçeği doldurmadan önce, "Bilgilendirilmiş Onam Formu" verilmiştir. Bu formlar ile katılımcılara çalışmanın amacı ve içeriği hakkında bilgi verilmiştir. Araştırmaya gönüllü olarak katılmayı onaylayan öğrencilere de, okul idaresinin belirttiği gün ve saatlerde Sosyodemografik Özellikler ve Bilgi Formu, Bilinçli Farkındalık Ölçeği (BİFÖ) ve DurumlukSürekli Kaygı Envanterinin olduğu bir ölçek grubu verilmiştir. Öğrencilere uygulanan ölçek grubu çalışmayı yürüten kişi tarafından sınıf içinde ve ders işlendiği zamanlarda uygulanarak elden toplanmıştır. Veri toplama sürecinin ardından 276 ergen ve 276 anne olmak üzere 552 katılımcıya ulaşılmış ve elde edilen verilerin değerlendirilmesi amacıyla istatistiksel analiz sürecine başlanmıştır.

\section{Verilerin Analizi}

Verilerin analizi "SPSS. 16 İstatistiksel Veri Analiz Programı" ile yapılmıştır. Medyatör etki analizi için Baron ve Kenny'nin (1986) modeli kullanılmıştır. Mediatör etki analizinin 4 koşulu bulunmaktadır ve koşullarına göre analiz yapılabilmesi için, ilk analiz adımımız "Pearson Korelasyon Analizi" ile anne kaygı düzeyi (anne durumluk kaygı, anne sürekli kaygı), ergen kayg1 düzeyi (ergen durumluk kayg1, ergen sürekli kayg1) ve ergenlere uygulanan BİFÖ değişkenleri arasındaki ilişkiyi incelemektir. Daha sonra Baron ve Kenny'nin (1986) ilk üç koşulunu sağlayan değişkenler arasında Basit Regresyon Analizi ve son koşul için de Hiyerarşik

Regresyon Analizi yapılmıştır. Bu analizler sonucu hesaplanan farklı beta değerlerinin anlamlılığı incelenmiştir. Elde edilen anlamlı sonuçlar Sobel testi ile sınanmış ve aktarılmıştır. 


\section{BULGULAR VE TARTIŞMA}

Araştırmanın bu aşamasında, ergenlerin annelerinin durumluk ve sürekli kaygı düzeyi ile ergenlerin durumluk ve sürekli kaygı düzeyi ve ergenlik dönemindeki bilinçli farkındalık düzeyleri arasındaki ilişkilere odaklanılmıştır. Şekil 1'de de görüldüğü üzere, BİFÖ’nün anne kaygı düzeyi ile ergen kaygı düzeyi arasındaki ilişkide medyatör görevinde olup olmadığının incelendiği bu analizin yordayıcı değişkeni anne kaygı düzeyi, yordanan değişkeni ergen kaygı düzeyi ve mediatör (aracı) değişkeni ise bilinçli farkındalık düzeyi olarak belirlenmiştir.

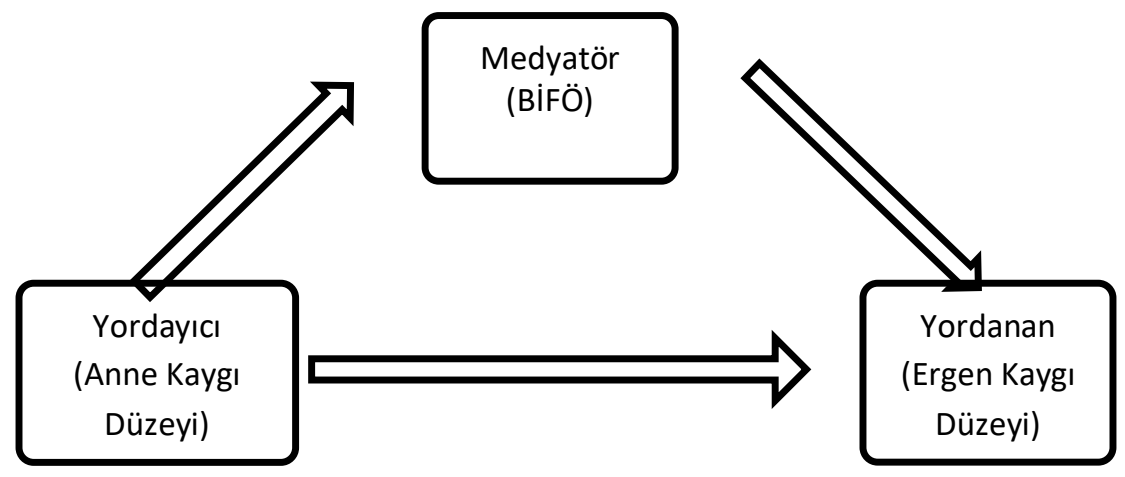

Şekil 1.Anne Kaygı Düzeyi ile Ergen Kaygı Düzeyi Arasındaki İlişkide BİFÖ’nün Medyatör Etkisi

Medyatör etki analizinin yapılabilmesi için öncelikle değişkenler arasındaki ilişkinin kontrolü gerekmektedir ve bu doğrultuda da "Pearson Korelasyon Testi" yapılmış, elde edilen veriler Tablo 1'de gösterilmiştir.

Tablo 1. Ergen Kayg1 Düzeyleri, Anne Kayg1 Düzeyleri ve Ergenlerin Bilinçli Farkındalık Düzeyleri Arasındaki Korelasyonlar

\begin{tabular}{lccccc}
\hline$\ddot{O} \boldsymbol{L C C E K}$ & $\begin{array}{c}\boldsymbol{A D K} \\
(\boldsymbol{n}=276)\end{array}$ & $\begin{array}{c}\boldsymbol{E D K} \\
(\boldsymbol{n}=276)\end{array}$ & $\begin{array}{c}\boldsymbol{B} \dot{\boldsymbol{I} F \boldsymbol{O}} \\
(\boldsymbol{n}=276)\end{array}$ & $\begin{array}{c}\boldsymbol{A S K} \\
(\boldsymbol{n}=276)\end{array}$ & $\begin{array}{c}\boldsymbol{E S K n} \\
(\boldsymbol{n}=276)\end{array}$ \\
\hline ADK & 1 & & & & \\
EDK &, $360^{* *}$ & 1 & & & \\
BIFÖ &,$- 263^{* *}$ &,$- 487^{* *}$ & 1 & & \\
ASK &, $292^{* *}$ &, $127^{*}$ &,$- 119^{*}$ & 1 & \\
ESK &, $347^{* *}$ &, $698^{* *}$ &,$- 422^{* *}$ &, $153^{*}$ & 1
\end{tabular}

Not: ADK anne durumluk kaygı ölçeğini, EDK ergen durumluk kaygı ölçeğini, BİFÖ bilinçli farkındalık ölçeğini, ASK anne sürekli kaygı ölçeğini, ESK ergen sürekli kaygı ölçeğini temsil etmektedir. ${ }^{*} p<.05, * * p<.01$

Araştırmaya ait tüm değişkenler arasında korelasyon sonuçları anlamlı olduğu için toplamda 4 ayrı medyatör modeline bakılmıştır. 
Tablo 2. Anne Durumluk Kaygı Düzeyi ile Ergen Durumluk Kaygı Düzeyi Arasındaki İlişkide Ergen Bilinçli Farkındalık Düzeyinin Aracı Rolüne İlişsin Regresyon Analiz Sonuçları

\begin{tabular}{|c|c|c|c|c|c|c|c|c|c|}
\hline MODEL 1 & 1 & $R$ & $\begin{array}{c}R^{2} \\
h S S s h s h \\
\end{array}$ & $\begin{array}{r}B \\
R 2 R R R 2 \\
\end{array}$ & SH & $\beta$ & $F$ & $t$ & $p$ \\
\hline$\stackrel{1}{X} \rightarrow Y$ & $\mathbf{X}$ &, 360 & , 129 & , 373 & ,058 & ,360 & 40,6 & 6,378 & ,001 \\
\hline$\stackrel{2}{X} \rightarrow M$ & $\mathbf{X}$ & ,263 & ,069 &,- 309 & ,069 &,- 263 & 20,3 & $-4,516$ & ,001 \\
\hline $\begin{array}{l}3 \\
M \Rightarrow Y\end{array}$ & $\mathbf{M}$ & ,487 & ,237 &,- 430 & ,047 & ,487 & 85,3 & $-9,237$ & ,001 \\
\hline 4 & $\mathbf{X}$ &, 543 & ,295 & ,258 & ,055 & ,248 & 64,1 & 4,717 &, 001 \\
\hline $\mathrm{XM} \Rightarrow \mathrm{Y}$ & $\mathbf{M}$ & ,543 & ,295 &,- 372 &,- 046 &,- 422 & 64,1 & $-8,009$ & ,001 \\
\hline
\end{tabular}

Not: X ile ifade edilen değişken anne durumluk kaygı düzeyi, y ile ifade edilen değişken ergen durumluk kaygı düzeyi ve M ile ifade edilen ise ergen bilinçli farkındalık düzeyidir.

Tablo 2'de yapılan regresyon analizleri incelendiğinde, Baron ve Kenny'nin (1986) ilk adımında, annelerin durumluk kaygı düzeyinin ergen durumluk kaygı düzeyi üzerinde anlamlı bir yordayıcı olduğu, diğer bir deyişle ergen durumluk kaygı düzeyi yordanan değişkenindeki varyansın yaklaşık \%13'ünün anne durumluk kaygı düzeyi ile açıklandığı görülmektedir $\left(\mathrm{R}^{2}=, 129, \beta=.360, p<.001\right)$. Bir sonraki adımda ise, anne durumluk kaygı düzeyinin aracı değişken olan ergen bilinçli farkındalık düzeyi üzerindeki etkisine odaklanılmış ve bu doğrultuda regresyon analizi yeniden kurgulanmıştır. Elde edilen sonuçlara göre, ergen bilinçli farkındalık düzeyindeki varyansın yaklaşık \% 7'sinin anne durumluk kaygı düzeyi tarafından açıklandığı ve söz konusu ilişkide anne durumluk kaygı düzeyinin anlamlı bir yordayıcı olduğu görülmüştür $\left(\mathrm{R}^{2}=, 069, \beta=-.263 p<.001\right)$. Üçüncü adımda, ergen bilinçli farkındalık düzeyinin ergenlerin durumluk kaygı düzeyi üzerindeki etkisine odaklanılmış ve bilinçli farkındalık düzeyinin ergenlerdeki durumluk kaygı düzeyindeki varyansın \%24'ünü açıkladı̆̆ı ve söz konusu ilişkide bilinçli farkındalık düzeyinin anlamlı bir yordayıcı olduğu bulunmuştur $\left(\mathrm{R}^{2}=\right.$ ,237, $\beta=.487 p<.001)$.

Baron ve Kenny'nin kriterlerine göre yapılan son adımında ise, aracı değişken ve yordayıcı değişken bir arada analize katılarak ergen durumluk kaygı düzeyi üzerindeki yordayıcı etkileri analiz edilmiştir. Söz konusu ilişkide tam medyatör etkiden bahsedebilmek için, daha önce anne durumluk kaygı düzeyinin anlamlı olan etkisinin kaybolması beklenmektedir. Yapılan analiz sonuçlarına göre, bilinçli farkındalık düzeyi ve anne durumluk kaygı düzeyi bir arada analize katıldığında, anne durumluk kaygı düzeyinin ergen durumluk kaygı düzeyi üzerindeki etkisinin kaybolmadığını anlamlılığını sürdürdüğünü fakat söz konusu ilişkideki $\beta$ kat sayıları incelendiğinde, anne durumluk kaygı düzeyinin tek başına yordayıcı etkisinin anlamlılığını sürdürdügünü fakat $\beta$ kat sayısı ,360 iken ergen bilinçli farkındalık düzeyi analize katıldığında $\beta$ kat sayısının ,248' e düştügü gözlemlenmiştir. Bu da akıllara tam bir medyatör etkiden var olmasa da değişkenler arasında kısmi medyatör etki olabileceği olasılığını getirmektedir. Söz konusu aracı etkinin anlamlılığını test etmek amaçlı Sobel $Z$ testi uygulanmıştır $(Z=3.91$, 
$p<.05)$. Elde edilen sonuçlar, yordayıcı değişkenin regresyon katsayısındaki azalmasının anlamlı bir azalma olduğunu göstermiştir, bu durum bilinçli farkındalığın kısmi aracı etkisinin anlamlı olduğunu ortaya koymaktadır. Başka bir ifadeyle, anne durumluk kaygı düzeyinin, ergen durumluk kaygı düzeyi üzerindeki etkisinin bir kısmı bilinçli farkındalık düzeyi ile açıklanabilmektedir.

Tablo 3. Anne Durumluk Kaygı Düzeyi İle Ergen Sürekli Kaygı Düzeyi Arasındaki İlişkide Ergen Bilinçli Farkındalık Düzeyinin Aracı Rolüne İlişkin Regresyon Analiz Sonuçları

\begin{tabular}{|c|c|c|c|c|c|c|c|c|c|}
\hline \multirow[t]{2}{*}{ MODEL } & \multirow[t]{2}{*}{2} & \multirow{2}{*}{$\boldsymbol{R}$} & \multicolumn{2}{|l|}{$R^{2}$} & \multirow[t]{2}{*}{ sh } & \multirow[t]{2}{*}{$\beta$} & \multirow[t]{2}{*}{$F$} & \multirow[t]{2}{*}{$t$} & \multirow[t]{2}{*}{$p$} \\
\hline & & & $\begin{array}{l}\text { hSH } \\
2 R R R 2 \\
\end{array}$ & Sshsh & & & & & \\
\hline \multicolumn{10}{|l|}{1} \\
\hline$X \Rightarrow Y$ & $\mathbf{X}$ & ,347 &, 120 & ,356 & 058 & ,347 & 37,8 & 6,122 &, 001 \\
\hline \multicolumn{10}{|l|}{2} \\
\hline $\mathrm{X} \rightarrow \mathrm{M}$ & $\mathbf{X}$ & ,263 & ,069 &,- 309 & ,069 &,- 263 & 20,3 & $-4,516$ &, 001 \\
\hline \multicolumn{10}{|l|}{3} \\
\hline $\mathrm{M} \Rightarrow \mathrm{Y}$ & M & ,422 & , 178 &,- 368 & ,048 &,- 422 & 59,3 & $-7,701$ & ,001 \\
\hline \multicolumn{10}{|l|}{$3-4$} \\
\hline & $\mathbf{X}$ & ,488 & ,238 & ,260 & 056 & ,253 & 42,0 & 4,627 &, 001 \\
\hline $\mathrm{XM} \rightarrow \mathrm{Y}$ & M & ,488 & ,238 &,- 310 & ,048 &,- 355 & 42,0 & $-6,483$ & ,001 \\
\hline
\end{tabular}

Not: X ile ifade edilen değişken anne durumluk kaygı düzeyi, y ile ifade edilen değişken ergen sürekli kaygı düzeyi ve M ile ifade edilen ise ergen bilinçli farkındalık düzeyidir.

Tablo 3'e bakıldığında, çalışmanın birinci adımında annelerin durumluk kaygı düzeyinin ergen sürekli kaygı düzeyi üzerinde anlamlı bir yordayıcı etkisi olduğu görülmüştür. Diğer bir deyişle ergen sürekli kaygı düzeyi yordanan değişkenindeki varyansın yaklaşık \%12'sinin anne durumluk kaygı düzeyi ile açıklandığı görülmektedir $\left(\mathrm{R}^{2}=, 120, \beta=.347, p<.001\right)$. İkinci adımda ise, anne durumluk kaygı düzeyinin aracı değişken olan ergen bilinçli farkındalık düzeyi üzerindeki etkisine ilişkin regresyon analizi sonucunun anlamlı olduğu, ergen bilinçli farkındalık düzeyi aracı değişkenindeki varyansın yaklaşık \%7'sinin anne durumluk kaygı düzeyi tarafından açıklandığı bulunmuştur $\left(\mathrm{R}^{2}=, 069, \beta=.263, p<.001\right)$. Üçüncü adımında, ergen bilinçli farkındalık düzeyinin ergen sürekli kaygı düzeyini yordamasına ilişkin analiz sonucunun anlamlı olduğu, ergen sürekli kaygı düzeyi yordanan değişkenindeki varyansın yaklaşık \%18'inin, ergen bilinçli farkındalık düzeyi tarafından açıklandığı görülmektedir $\left(\mathrm{R}^{2}=, 178, \beta=-.422, \mathrm{p}<.001\right)$. Dördüncü ve son adımda ise, anne durumluk kayg1 düzeyi ve ergen bilinçli farkındalık düzeyi bir arada analize katılarak ergen sürekli kaygı düzeyi üzerindeki yordayıcı etkileri analiz edilmiştir. Söz konusu ilişkide tam medyatör etkiden bahsedebilmek için, daha önce annenin durumluk kaygı düzeyinin anlamlı olan etkisinin kaybolması beklenmektedir. Yapılan analiz sonuçlarına göre, bilinçli farkındalık düzeyi ve anne durumluk kaygı düzeyi bir arada analize katıldığında, anne durumluk kaygı düzeyinin ergen sürekli kaygı düzeyi üzerindeki etkisinin kaybolmadığını anlamlılığını sürdürdüğünü fakat söz konusu ilişkideki $\beta$ kat sayıları incelendiğinde, anne durumluk kaygı düzeyinin tek başına yordayıcı 
olduğundaki $\beta$ kat sayısı ,347 iken, ergen bilinçli farkındalık düzeyi ile analize katıldığında $\beta$ kat sayısı ,253' e düşmüştür. Bu da akıllara tam bir medyatör etkiden bahsedilmese de kısmi bir medyatör etki olasılığını getirmektedir. Bu medyatör etkinin anlamlılığını test etmek amaçlı da Sobel $Z$ testi uygulanmıştır $(Z=3.68, p<.05)$. Elde edilen sonuçlar, yordayıcı değişkenin regresyon katsayısındaki azalmasının anlamlı bir azalma olduğunu göstermiş olup, bilinçli farkındalığın kısmi aracı etkisinin anlamlı olduğunu göstermektedir. Başka bir deyişle anne durumluk kaygı düzeyinin ergen sürekli kaygı düzeyi üzerindeki etkisinin bir kısmı bilinçli farkındalık düzeyi ile gerçekleşmektedir.

Tablo 4: Anne Sürekli Kaygı Düzeyi İle Ergen Durumluk Kaygı Düzeyi Arasındaki İlişkide Bilinçli Farkındalık Düzeyinin Aracı Rolüne İlişkin Regresyon Analiz Sonuçları

\begin{tabular}{|c|c|c|c|c|c|c|c|c|c|}
\hline \multirow{2}{*}{\multicolumn{10}{|c|}{ Sshsh R 2RR2 }} \\
\hline & & & & & & & & & \\
\hline$\underset{2}{X \rightarrow Y}$ & $\mathbf{X}$ &, 127 &, 016 &, 220 &, 104 & , 127 & 4,48 & 2,118 &, 001 \\
\hline $\mathrm{X} \rightarrow \mathrm{M}$ & $\mathbf{X}$ & ,119 &, 014 &,- 234 & ,118 &,- 119 & 20,3 & $-1,987$ &, 048 \\
\hline \multirow{3}{*}{$\begin{array}{l}3 \\
M \Rightarrow Y \\
3-4\end{array}$} & & & & & & & & & \\
\hline & $\mathbf{M}$ & ,487 & ,237 &,- 430 & 047 &,- 487 & 85,3 & $-9,237$ &, 001 \\
\hline & $\mathbf{X}$ & ,492 & ,242 &, 121 & ,092 & ,070 & 42,0 & 1,316 & , 189 \\
\hline $\mathrm{XM} \Rightarrow \mathrm{Y}$ & $\mathbf{M}$ & ,492 & ,242 &,- 422 &, 047 &,- 479 & 42,0 & $-9,027$ &, 001 \\
\hline
\end{tabular}

Not: X ile ifade edilen değişken anne sürekli kaygı düzeyi, y ile ifade edilen değişken ergen durumluk kaygı düzeyi ve $\mathrm{M}$ ile ifade edilen değişken ise ergen bilinçli farkındalık düzeyidir.

Tablo 4'e baktığımızda, Baron ve Kenny (1986) kriterlerine göre geliştirilen 3. model için yapılan regresyon analizlerinin birinci adımında, annenin sürekli kaygı düzeyinin ergen durumluk kaygı düzeyi üzerinde anlamlı bir yordayıcı etkisi olduğu bulunmuştur. Diğer bir deyişle ergen durumluk kaygı düzeyi yordanan değişkenindeki varyansın yaklaşık \%2'sinin anne sürekli kaygı düzeyi ile açıklandığı görülmektedir $\left(\mathrm{R}^{2}=, 016, \beta=.127, \mathrm{p}<.001\right)$. Bir sonraki adımda ise, anne sürekli kaygı düzeyi, aracı değişken olan ergen bilinçli farkındalık düzeyi üzerindeki etkisine ilişkin regresyon analizi sonucunun anlamlı olduğu, ergen bilinçli farkındalık düzeyi aracı değişkenindeki varyansın yaklaşık \%2'sinin anne sürekli kaygı düzeyi tarafından açıklandığı bulunmuştur $\left(\mathrm{R}^{2}=, 014, \beta=-.119, \mathrm{p}<.001\right)$. Üçüncü adımında, ergen bilinçli farkındalık düzeyinin ergen durumluk kaygı düzeyini yordamasına ilişkin analiz sonucunun anlamlı olduğu, ergen durumluk kaygı düzeyi yordanan değişkenindeki varyansın yaklaşık \%24'ünün, ergen bilinçli farkındalık düzeyi tarafından açıklandığı görülmektedir $\left(\mathrm{R}^{2}=, 237, \beta=-.487, \mathrm{p}<.001\right)$.

Baron ve Kenny'nin kriterlerine göre yapılan son adımda ise, aracı değişken ve yordayıcı değişkenin bir arada analize katılarak ergen durumluk kaygı düzeyi üzerindeki yordayıcı etkileri analiz edilmiştir. Söz konusu ilişkide tam medyatör etkiden bahsedebilmek için, daha önce annenin sürekli kaygı düzeyinin anlamlı olan etkisinin kaybolması beklenmektedir. Yapılan analiz sonuçlarına göre, bilinçli farkındalık düzeyi ve anne sürekli kaygı düzeyi bir 
arada analize katıldığında, anne sürekli kaygı düzeyinin ergen durumluk kaygı düzeyi üzerinde daha önce anlamlı olan etkisinin anlamlılığını yitirdiği görülmektedir (p>.05). Söz konusu ilişkideki $\beta$ kat sayıları incelendiğinde anne sürekli kaygı düzeyinin tek başına yordayıcı olduğundaki $\beta$ kat sayısı ,127 iken ergen bilinçli farkındalık düzeyi ile analize katıldığında $\beta$ kat sayısının ,070' e düştüğü gözlenmiştir. Söz konusu değişkenler arası anlamlılığın kaybolması bize tam bir medyatör etkinin olduğunu göstermektedir. Diğer bir deyişle anne sürekli kaygı düzeyinin ergen durumluk kaygı düzeyi üzerindeki etkisinin gerçekleşmesinde bilinçli farkındalık düzeyi anlamlı ve tam bir aracı rol üstlenmektedir.

Tablo 5. Anne Sürekli Kaygı Düzeyi İle Ergen Sürekli Kaygı Düzeyi Arasındaki İlişkide Ergen Bilinçli Farkındalık Düzeyinin Aracı Rolüne İlişkin Regresyon Analiz Sonuçları

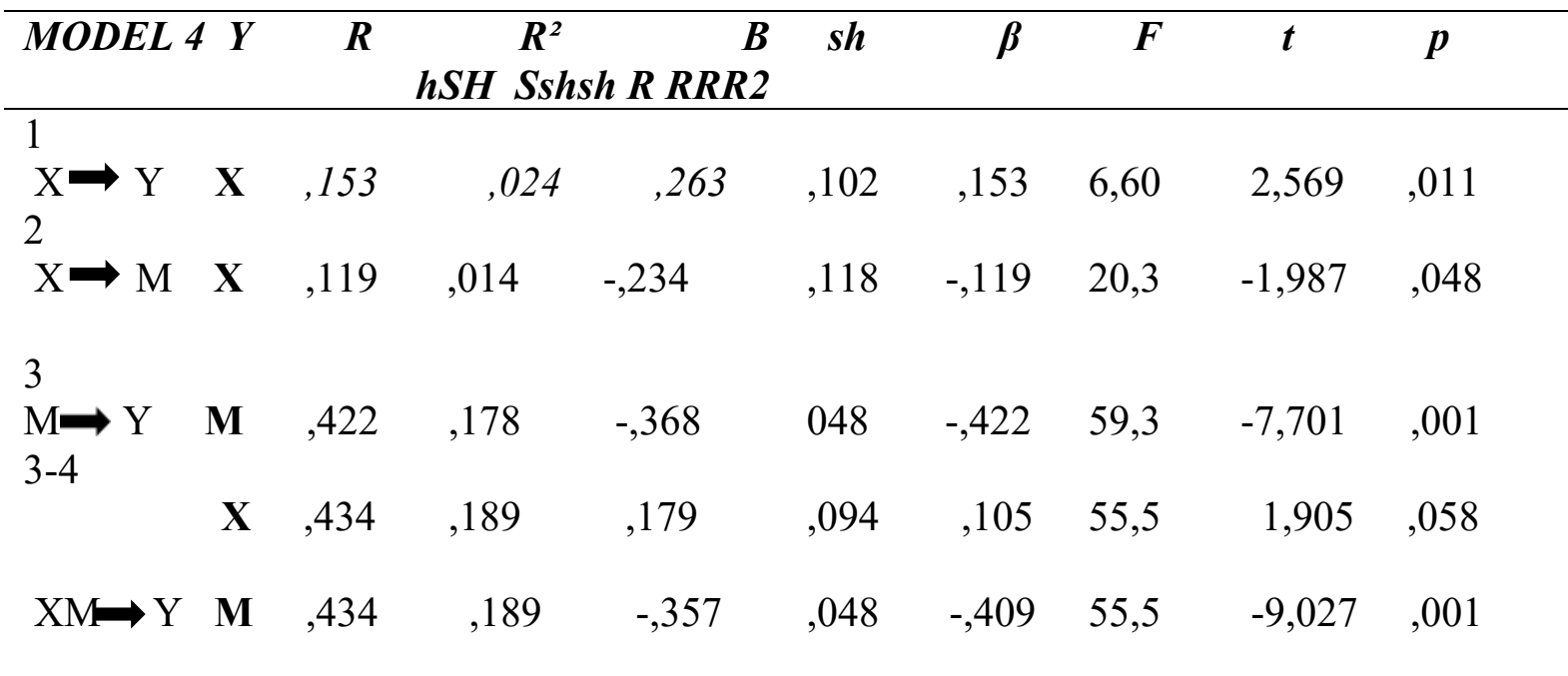

Not: X ile ifade edilen değişken anne sürekli kaygı düzeyi, y ile ifade edilen değişken ergen sürekli kaygı düzeyi ve $\mathrm{M}$ ile ifade edilen ise ergen bilinçli farkındalık düzeyidir.

Tablo 5'te görüldüğü üzere, yapılan regresyon analizleri incelendiğinde, Baron ve Kenny'nin (1986) ilk adımında, annelerin sürekli kaygı düzeyinin ergen sürekli kaygı düzeyi üzerinde anlamlı bir yordayıcı olduğu, başka bir deyişle ergen sürekli kaygı düzeyi yordanan değişkendeki varyansın yaklaşık \%3'ünün anne sürekli kaygı düzeyi ile açıklandığı görülmektedir $\left(\mathrm{R}^{2}=, 024, \beta=.153, p<.001\right)$. Bir sonraki adımda ise, anne sürekli kaygı düzeyinin aracı değişken olan ergen bilinçli farkındalık düzeyi üzerindeki etkisine odaklanılmış ve bu doğrultuda regresyon analizi yeniden kurgulanmıştır. Elde edilen sonuçlara göre, ergen bilinçli farkındalık düzeyindeki varyansın yaklaşık \%2'sinin anne durumluk kaygı düzeyi tarafından açıklandığı ve söz konusu ilişkide anne durumluk kaygı düzeyinin anlamlı bir yordayıcı olduğu görülmüştür $\left(\mathrm{R}^{2}=, 014, \beta=-.119, p<.001\right)$. Üçüncü adımda ise ergen bilinçli farkındalık düzeyinin ergenlerin sürekli kaygı düzeyi üzerindeki etkisine odaklanılmış ve bilinçli farkındalık düzeyinin ergenlerdeki sürekli kaygı düzeyi üzerindeki varyansın \%18'ini açıkladığı ve söz konusu ilişkide bilinçli farkındalık düzeyinin anlamlı bir yordayıcı olduğu bulunmuştur $\left(\mathrm{R}^{2}=, 178, \beta=-.422, p<.05\right)$.

Baron ve Kenny'nin kriterlerine göre yapılan son adımda ise, anne sürekli kaygı düzeyi ve bilinçli farkındalık düzeyi bir arada analize katılarak ergen sürekli kaygı düzeyi üzerindeki yordayıcı etkileri analiz edilmiştir. Söz konusu ilişkide tam medyatör etkiden bahsedebilmek için, daha önce annenin sürekli kaygı düzeyinin anlamlı olan etkisinin kaybolması beklenmektedir. Yapılan analiz sonuçlarına göre, bilinçli farkındalık düzeyi ve anne sürekli 
kaygı düzeyi bir arada analize katıldığında, anne sürekli kaygı düzeyinin ergen sürekli kaygı düzeyi üzerinde daha önce anlamlı olan etkisinin anlamlılığını yitirdiği görülmektedir. Söz konusu ilişkideki $\beta$ kat sayıları incelendiğinde, anne sürekli kaygı düzeyinin tek başına yordayıc1 olduğundaki $\beta$ kat sayısı ,153 iken ergen bilinçli farkındalık düzeyi ile analize katıldığında $\beta$ kat sayısının ,105'e düştüğü gözlenmiştir. Söz konusu değişkenler arası anlamlılığın kaybolması bize tam bir medyatör etkinin olduğunu göstermektedir. Başka bir deyişle anne sürekli kaygı düzeyinin ergen sürekli kaygı düzeyi üzerindeki etkisinde bilinçli farkındalık düzeyi anlamlı ve tam bir aracı rol üstlenmektedir.

\section{Tartışma}

Bu çalışmada, ergen kaygı düzeyi ile anne kaygı düzeyi arasındaki ilişkide, ergenlerin bilinçli farkındalık düzeyinin aracı etkisi incelenmiştir. Çalışmanın bu ilişkiyi ele almasının sebebi ise literatür verileri incelendiğinde, daha önce çocuğun kaygısı ile annenin kaygısı arasındaki ilişskinin anlamlılığına (Geçtan, 1995; Çifter, 1985; Yavuzer, 1994; Yıldırım, 2018; Ulutaş ve Alisinanoğlu, 2003), bilinçli farkındalık düzeyi ile kaygı düzeyi arasındaki ilişkinin anlamlılığına ve (Ülev, 2014; Kocaefe, 2013; Hisli-Şahin ve Yeniçeri, 2015) bilinçli farkındalık temelli uygulamalar ile kaygı düzeyi arasındaki ilişkinin anlamlılığına (Mercer ve ark., 2006; Kabat-Zinn ve ark., 1985; Semple ve ark., 2009; Roemer ve ark., 2009; Vollestad ve ark., 2012; Vollestad, Sivertsen, Nielsen, 2011) odaklanan çok sayıda araştırma olmasına rağmen, 14-17 yaş aralığındaki ergenleri kapsayan, anneler ve ergenlerin kaygı düzeyi arasındaki ilişkide ergenin bilinçli farkındalık düzeyinin aracı etkisini inceleyen araştırmaların sınırlı sayıda olmasidir.

Çalışmanın ilk analiz adımında, ergen kaygı düzeyinin değişkenleri olan ergen durumluk kaygı düzeyi, ergen sürekli kaygı düzeyi ve anne kaygı düzeyinin değişkenleri olan anne durumluk kaygı düzeyi, anne sürekli kaygı düzeyi ile ergenlerin bilinçli farkındalık düzeyleri arasındaki olası ilişki incelenmiş ve söz konusu ilişkide çalışmanın ilk ana hipotezi olarak ergen kaygı düzeyi ile anne kaygı düzeyi arasındaki ilişkide, ergenlerin bilinçli farkındalık düzeyinin aracı etkisine odaklanılmıştır.

Baron ve Keny'nin aracı etki analiz adımları doğrultusunda araştırmanın ilk temel hipotezi ergenler ve annelerinin kaygı düzeyleri arasındaki ilişkide ergenin bilinçli farkındalık düzeyinin aracı etkisinin incelenmesi olduğundan, söz konusu ilişkiye yönelik ilk işlemsel hipotez anne kaygı düzeyinin (durumluk ve sürekli kaygı) ergenin kaygı düzeyi (durumluk ve sürekli kaygı) üzerinde anlamlı bir yordayıcı etkiye sahip olması şeklindeydi. Hipoteze paralel olarak, çalışma sonucunda anne durumluk kaygı düzeyi ile ergen durumluk kaygı düzeyi arasında ve anne durumluk kaygı düzeyi ile ergen sürekli kaygı düzeyi arasında pozitif yönlü ve anlamlı bir ilişki olmakla birlikte, regresyon analizi sonucuna göre de anne durumluk kaygı düzeyinin ergenin durumluk ve sürekli kaygı düzeyi üzerindeki etkisinin anlamlı olduğu saptanmıştır. Aynı zamanda anne sürekli kaygı düzeyi ile ergen durumluk kaygı düzeyi arasında ve anne sürekli kaygı düzeyi ile ergen sürekli kaygı düzeyi arasında pozitif yönde anlamlı bir ilişki olmakla birlikte, regresyon analizi sonucuna göre anne sürekli kaygı düzeyinin ergenin durumluk ve sürekli kayg1 düzeyi üzerindeki etkisinin anlamlı olduğu bulunmuştur. $\mathrm{Bu}$ sonuçlarla ilişkilendirebileceğimiz literatür çalışmalarına baktığımızda, bizim çalışmamızla benzer sonuçların elde edildiği çalışmalara rastlamak mümkündür. $\mathrm{Bu}$ bağlamda, Ulutaş ve Alisinanoğlu (2003) tarafından yapılan bir araştırmada 10 yaşındaki çocukların sürekli kaygı düzeyleri ile annelerinin sürekli kaygı düzeyleri arasındaki ilişki incelenmiş ve araştırma sonucunda anlamlı bir ilişkinin olduğu saptanmıştır. Örneklemi 10-14 yaş aralığındaki 
çocukları kapsayan Tükel (2000) tarafından yapılan başka bir araştırmada ise, anksiyöz yapıya sahip annedeki anksiyete düzeyi ile çocuktaki anksiyetenin benzerlik gösterdiği, çocuğa bir şekilde bulaştı̆̆ 1 böylelikle çocukta da kaygının olduğu ortaya çıkmıştır. Tüm bunlara ek olarak, Martini, Knappe, Beesdo-Baum ve Lieb (2010) kayg1 duygusunun annelerden çocuklarına bulaştığını dile getirmiştir. Öğrenciler ve anneleri üzerinde yapılan bir araştırmada, öğrencilerin üniversite sınavına dair kaygıları, bağlanma stilleri ve annelerinin kaygı düzeyleri arasındaki ilişki incelenmiştir. Bu çalışma sonucunda da annelerin durumluk kaygı düzeyleri ile öğrencilerin sınav kaygı düzeyleri arasında anlamlı bir ilişki bulunmuştur (Aydın, 2018). Abacı (1986), çalışmasında durumluk ve sürekli kaygı düzeyi ile anne baba yaklaşımları arasındaki ilişkileri incelemiş ve anlamlı sonuçlar bulmuştur. Son olarak, Duman (2008) tarafindan ilköğretim 8. sınıf öğrencilerine yapılan araştırmada öğrencilerin durumluk sürekli kaygı düzeyleri ile anne - baba yaklaşımları arasında anlamlı bir ilişki olduğu belirlenmiştir (Duman, 2008). Dolayısıyla temel hipoteze ait analiz bulguları tüm bu araştırmalar ile tutarlı olarak anne kayg1 düzeyinin ergen kaygı düzeyi üzerinde etkili olduğuna işaret etmektedir. Bu araştırmadan elde edilen anne kaygı düzeyinin ergen kaygı düzeyini yordaması sonucuna bakarak, çocuk ve ergenlerde kaygı çalışırken anneye odaklanmanın ne kadar önemli olduğu, dolayısıyla zaman zaman ebeveynlerin de hem psikoeğitimle veya terapi desteği ile çocuğun terapi sürecine katk1 sunulabileceği düşünülmektedir. Aynı zamanda, elde edilen bu sonucun bu alanda yapılacak gelecek araştırmalara da katkı sağlayacağı düşünülmektedir.

Araştırmanın diğer bir işlemsel hipotezi, anne kaygı düzeyinin (durumluk ve sürekli kaygı), ergenin bilinçli farkındalık düzeyi üzerinde anlamlı bir yordayıcı etkiye sahip olması yönündedir. Buna yönelik yapılan analiz sonucunda, hipotezle aynı doğrultuda anlamlı sonuçlar bulunmuştur. Elde edilen bulgulara göre, anne durumluk kaygı düzeyi ile ergen bilinçli farkındalık düzeyi arasında negatif yönlü ve anlamlı bir ilişki olmasının yanı sıra, söz konusu ilişkide anne durumluk kaygı düzeyinin ergenin bilinçli farkındalık düzeyi üzerindeki yordayıcı etkisinin anlamlı olduğu bulunmuştur. Bu sonuçlara paralel olarak, bilinçli farkındalık düzeyi ile anne sürekli kaygı düzeyi arasında negatif yönlü ve anlamlı bir ilişki var iken, regresyon analizi sonucuna göre, ergen bilinçli farkındalık düzeyi aracı değişkeninin anne sürekli kaygı düzeyi tarafından yordandığı saptanmıştır. Literatür verileri incelendiğinde, Türkiye'de de son yıllarda üzerinde durulan bilinçli farkındalığın kaygı ile ilişkisi olduğuna işaret eden araştırmalara rastlanmıştır (Kocaefe, 2013; Hisli-Şahin ve Yeniçeri, 2015; Ülev, 2014). Buna ek olarak, literatürde kaygı düzeyi üzerinde bilinçli farkındalığın etkisini değerlendiren araştırmalar da bulunmaktadır. Mercer ve arkadaşları da yaptıkları araştırmada, bilinçli farkındalığa dayalı bilişsel terapinin birinci basamakta, ortalama kaygı puanlarında istatistiksel olarak anlamlı azalma yarattığını ortaya koymuştur. Vollestad ve arkadaşlarının (2011) çalışmasında da bilinçli farkındalık temelli stres azaltmanın anksiyete bozuklukları ve ilgili belirtiler için etkili bir tedavi olduğu öne sürülmüştür. Yine Vollestad ve arkadaşlarının 2012 yılında yaptığı çalışmada, bilinçli farkındalık ve kabul temelli yaklaşımların, anksiyete belirtilerinde sağlam ve önemli azalmalar yarattığ görülmüştür. Tüm bunlara ek olarak, Shapiro, Brown ve Biegel (2007)'ın yürüttükleri bir araştırmada, katılımcılara uygulanan ve sekiz hafta süren "Bilinçli Farkındalık Temelli Stres Azaltma" müdahalesi sonrasında katılımcıların sürekli kaygı düzeyinin azaldığı görülmüştür. Araştırmanın bulguları literatürdeki çalışmalara benzer bulgular ortaya koyduğundan, anne kaygı düzeyinin ergenin bilinçli farkındalık düzeyi üzerinde etkili olduğu söylenebilir. Bu sonuç, gelecek araştırmalara yeni bir 1şık tutmakla birlikte ele aldı̆̆ımız bu değiş̧kenlerin klinik uygulamalarda göz önünde bulundurulması, bu yöndeki psikolojik belirtilerin temelinin daha iyi anlaşılmasını sağlayacak ve bu da tedavi sürecini kolaylaștıracaktır. 
Araştırmadaki diğer bir işlemsel hipotez, ergenlerde bilinçli farkındalık düzeyinin, ergen kaygı düzeyi (durumluk ve sürekli) üzerinde anlamlı bir yordayıcı etkiye sahip olmasıdır. Yine araştırma sonucunda bu yönde anlamlı sonuçlar bulunmuştur. $\mathrm{Bu}$ sonuçlara göre, ergen durumluk kaygı düzeyi ile ergen bilinçli farkındalık düzeyi arasında negatif yönlü ve anlamlı bir ilişki söz konusuyken, bu ilişkide bilinçli farkındalık düzeyinin ergen durumluk kaygı düzeyi üzerindeki etkisinin anlamlı bulunmuştur. Diğer yandan ergen bilinçli farkındalık düzeyi ile ergen sürekli kaygı düzeyi arasında negatif yönlü ve anlamlı bir ilişki varken, ergen bilinçli farkındalık düzeyinin ergen sürekli kaygı düzeyini yordadığı dolayısıyla bilinçli farkındalığın ergen sürekli kaygı düzeyi üzerindeki etkisinin anlamlı olduğu görülmektedir. Bu bağlamda literatürdeki araştırmalar incelendiğinde, bu çalışmayla paralel olarak Kısmetoğlu (2019)'nun 15-18 yaşındaki ergenlerle yürüttüğü araştırmada, bilinçli farkındalık düzeyi ile kaygı düzeyi arasındaki ilişkinin negatif yönlü ve anlamlı olduğunu bulunmuştur (Kısmetoğlu, 2019). Semple ve arkadaşlarının (2009) yaptığı başka bir araştırmada, 9-13 yaş aralığında olan ve yüksek anksiyete düzeyi saptanan çocuklar için bilinçli farkındalık temelli bilişsel terapinin (MBCT-C), kaygı semptomlarında belirgin bir azalma sağladığ 1 tespit edilmiştir. Roemer ve arkadaşlarının (2009) çalışmasında ise, duygu düzenlemede zorluk yaşayan ve kaygı düzeyleri yüksek olan bireylerde bilinçli farkındalık programının etkili olduğu görülmüştür. Bunlara ek olarak, Kabat-Zinn ve arkadaşlarının (1985) yaptığı bir çalışmaya göre, uygulanan bilinçli farkındalık temelli grup programının katılımcıların kaygı, panik bozukluğu ve fobi belirtilerinde belirgin bir azalmaya neden olduğu belirtilmiştir. Yine bu araştırmayla aynı doğrultuda sonuçlara ulaşan (Ülev, 2014; Mercer ve ark., 2006; Shapiro ve ark., 1998; Vollestad ve ark., 2012; Vollestad ve ark., 2011) yani bilinçli farkındalığın kaygı düzeyini azalttığını gösteren çalışmalar bulunmaktadır. Tüm bu verileri değerlendirdiğimizde, mevcut araştırmanın sonuçları literatürdeki çalışmalar ile uyumlu olarak ergen bilinçli farkındalık düzeyinin ergenin kaygı düzeyi üzerinde anlamlı bir etki yarattı̆ğna işaret etmektedir. Söz konusu ilişkiden elde edilen sonuçtan yola çıkarak, klinik uygulamalara kaygı sorunlarıyla başvuran ergenlere, bilinçli farkındalık temelli uygulamalar eklenmesinin ergenlerin tedavi sürecine katkı sağlayacağı düşünülmektedir.

Araştırmanın bir sonraki adımında elde edilen bulgularda, Baron ve Kenny'nin (1986) medyatör etki analizinin ilk üç koşulu da gerçekleştiği için son adım olan bilinçli farkındalık düzeyinin medyatör etkisi incelenmiştir. Burada son işlemsel hipotez, ergenlerde bilinçli farkındalık düzeyinin etkisi kontrol edildiğinde, anne kaygı düzeyinin (durumluk ve sürekli) ergenin kaygı düzeyi (durumluk ve sürekli) üzerindeki etkisinin anlamlılığını kaybetmesi şeklindeydi. Dolayısıyla bu hipoteze göre dört medyatör modeli incelenmiştir. Söz konusu hipotez temel alınarak oluşturulan dört medyatör analizinin birinci modelinde, anne durumluk kaygı düzeyi ile ergen durumluk kaygı düzeyi arasındaki ilişkide ergen bilinçli farkındalık düzeyinin aracı etkisi incelenmiştir. Yapılan analize göre, anne durumluk kaygı düzeyi ile ergen durumluk kaygı düzeyi arasındaki ilişkide ergenlerin bilinçli farkındalık düzeyinin kısmi aracı etkiye sahip olduğu bulunmuştur. Literatür verileri incelendiğinde, söz konusu ilişkileri aracilık hipotezleri üzerinden inceleyen bir araştırma bulunmadığından, bu çalışmanın aracı hipotezlere dair bulguları literatür verileriyle karşılaştırılamamıştır. Araştırmadan elde edilen bu bulgu değerlendirildiğinde ise ergenlerin kaygı düzeylerine müdahale etmek üzere gerçekleştirilen psikoterapi uygulamalarına, ergen kaygı düzeyi ile ebeveyn kaygı düzeyini düzenlemeye yönelik uygulamaların yanı sıra, ergenlerdeki bilinçli farkındalık düzeyini arttırmaya yönelik uygulamaların eklenmesinin ne derece önemli olduğu ortaya çıkmaktadır. Gelecek araştırmalarda farklı yaş gruplarında, farklı illerdeki öğrencilerde veya örneklem sayısı arttırılarak bu sonucun etkililiği sınanabilir. 
Araştırmanın son işlemsel hipotez dikkate alınarak oluşturulan ikinci medyatör modelinde, ergenlerin bilinçli farkındalık düzeyi ile anne durumluk kaygı düzeyi bir arada analize katılarak, ergenlerin sürekli kayg1 düzeyi üzerindeki etkileri incelenmiştir. Elde edilen bulgulara göre, anne durumluk kayg1 düzeyinin ergen sürekli kayg1 düzeyi üzerindeki etkisinde bilinçli farkındalık düzeyinin kısmı bir aracı role sahip olduğu görülmüştür. Bu bulgu literatüre katkı sağlamasının yanı sıra, özellikle kaygı sorunları yaşayan ergenlerde uygulanacak bilinçli farkındalık temelli çalışmaların tedavi sürecine katkısını göstermektedir.

Son işlemsel hipotez temel alınarak oluşturulan medyatör analizinin üçüncü modelinde ise, anne sürekli kaygı düzeyi ile ergen bilinçli farkındalık düzeyi bir arada analize katılarak ergen durumluk kaygı düzeyi üzerindeki etkileri incelenmiştir. Yapılan analiz sonuçlarına göre, anne sürekli kaygı düzeyinin ergen durumluk kaygı düzeyi üzerindeki anlamlı etkisinin aracı değişken etkisi kontrol edildiğinde anlamlılığını kaybettiği görülmüştür. Diğer bir deyişle anne sürekli kaygı düzeyinin ergen durumluk kaygı düzeyi üzerindeki etkisinde bilinçli farkındalığın tam medyatör etkisi olduğu saptanmıştır. Literatür verileri incelendiğinde, söz konusu ilişsileri aracılık hipotezleriyle inceleyen çalışmalar sınırlı olmakla birlikte, benzer değişkenler arasındaki ilişkileri analiz eden araştırmalar dikkat çekmektedir. Örneğin; Cesur ve arkadaşları (Cesur, Sayraç, Korkmaz, 2018) çocukluk dönemindeki örselenme deneyimlerinin sürekli kaygı düzeyindeki doğrudan ve bilinçli farkındalık düzeyindeki dolaylı etkilerini incelemiştir. Analiz sonucunda sürekli kaygı düzeyinde bilinçli farkındalığın aracı bir etki üstlendiğini saptamıştır. Bu araştırma literatürde ilk kez gerçekleştirilen bir çalışma olduğu için, bu anlamlı sonucun literatür için önemli bir bulgu olacağı dolayısıyla gelecekte bu yönde yapılacak araştırmalara 1şık tutacağ1 söylenebilir. Elde edilen bu bulgunun günümüzde ergenleri büyük oranda etkileyen "kaygı" ve sebep olduğu fiziksel/psikolojik rahatsızlıklara yönelik tedavilere katkıda bulunması beklenmektedir.

Son işlemsel hipotez dikkate alınarak oluşturulan medyatör modelinin dördüncü yani son modelinde de, anne sürekli kaygı düzeyi ile ergen bilinçli farkındalık düzeyi bir arada analize katıldığında ergen sürekli kaygı düzeyi üzerindeki etkileri incelenmiştir. Yapılan analiz sonuçlarına göre söz konusu değişkenler arası ilişkinin aracı etkiyle beraber anlamlılı̆̆ını kaybettiği görülmektedir. Elde edilen bulgulara göre, anne sürekli kaygı düzeyinin ergen sürekli kaygı düzeyi üzerindeki etkisinde bilinçli farkındalık düzeyinin anlamlı ve tam bir aracı rol üstlendiği görülmektedir. Literatürdeki veriler incelendiğinde, Cesur ve arkadaşlarının (2018) yaptığı çalışmada çocukluk dönemindeki örselenme deneyimlerinin sürekli kaygı düzeyi ve bilinçli farkındalık faktörleri ile ilişkisi incelenmiştir ve analiz sonucunda sürekli kaygı düzeyinde bilinçli farkındalığın aracı bir etki üstlendiği saptanmıştır. Bu sonuçlardan yola çıarak araştırmanın bulgularının araştırmanın temel hipoteziyle ve literatürle uyumlu olduğu söylenebilir. Dolayısıyla söz konusu ilişkideki saptanan anlamlı sonuçların ileriki araştırma konuları için literatüre farklı bir bakış sunduğu düşünülmektedir. Bununla birlikte bu anlamlı sonuç, anne ile yapılan çalışmalarda veya anne eğitim seminerlerinde, kaygı temelli sorunlar için klinik uygulamalarda kullanılabilir. Ek olarak, ergenlerde bilinçli farkındalık temelli uygulamaların yapılması, ergenin aile ve eğitim hayatına olumlu katkı sağlayabilir.

\section{SONUÇ VE ÖNERILER}

Sonuç olarak, anne kaygı düzeyi (durumluk ve sürekli), ergen kaygı düzeyi (durumluk ve sürekli) ve bilinçli farkındalık düzeyi arasındaki korelatif ilişkilerin anlamlı olmasından dolayı medyatör etki analizi gerçekleştirilmiştir. Araştırmada anne durumluk kaygı düzeyi ile ergen 
kaygı düzeyi (durumluk ve sürekli) arasındaki ilişkide bilinçli farkındalığın kısmi aracı etkisinin bulunduğu, anne sürekli kaygı düzeyi ile ergen kaygı düzeyi (durumluk ve sürekli) arasındaki ilişkide ise bilinçli farkındalığın tam aracı etkiye sahip olduğu bulunmuştur. Bu bulgularla birlikte, literatürde bu üç değişkenin bir arada değerlendirildiği çalışmaların sınırlı sayıda olması nedeniyle araştırmanın literatüre önemli bir katkı sağladığı düşünülmektedir. Özetle, bu araştırmanın bilinçli farkındalık kavramına yönelik gelecek çalışmalara ve bu kavramın bilinirliğinin arttırılmasına katkıda bulunması beklenmektedir. Bu bağlamda, bu çalışmanın temel sonucu olarak anne sürekli kaygı düzeyi ile ergen kaygı (durumluk ve sürekli) düzeyi arasındaki ilişkide bilinçli farkındalığın aracı etkisinin bulunmuş olmasının gerek teorik gerek pratik zeminde önemli etkilerinin olabileceği düşünülmektedir. Tüm bu verilerden yola çıkarak araştırmanın sınırlılıklarına baktığımızda, bu çalışma İstanbul ili Kâğıthane ve Beşiktaş ilçesindeki Özel ve Devlet Anadolu liselerinde öğrenim gören öğrenciler ile yapılmıştır. Bu nedenle Anadolu liseleri dışındaki liselere ve farklı ilçelerde okuyan öğrencilere genelleme yapmayı zorlaştırmaktadır. Gelecek çalışmalarda da farklı ilçelerde farklı lise türlerinde çalışmanın etkililiği sınanabilir.

Diğer yandan örneklemin sadece 14-17 yaş grubundaki lise öğrencilerini kapsamasından dolayı katılımcılar farklı yaş aralığındaki bireylere genelleme yapmak güç olmaktadır. Bu nedenle gelecek çalışmalarda farklı yaş grupları ile söz konusu ilişki incelenebilir. Bununla birlikte, ölçekleri annelere uygulamada bir gözetim yapılamadığından, katılımcıların ölçekleri nasıl yanıtladıkları konusundaki denetim azalmıştır ve bu da araştırmanın veri toplama kısmı için bir sınırlılık oluşturmaktadır. Bunlara ek olarak, uygulanan ölçeklerin kişilerin kendi bildirimine dayalı olması her katılımcı için bir yanlılık oluşturabilmektedir.

Diğer yandan ülkemizde bilinçli farkındalık ile yapılan araştırmaların azlığı dikkate alınarak gelecek araştırmaların bu alana odaklanmasının desteklenmesi gerekmektedir. Bu yöndeki araştırmalar, ölçeğin Türkçe formunun bilinçli farkındalık düzeyini ölçme konusunda yeterliliğini test etmek için önemli olmaktadır. Bununla birlikte, bu araştırma ilişkisel tarama modelindedir fakat bilinçli farkındalıkla ilgili deneysel araştırmaların da yapılması faydalı olabilir.

Bilinçli farkındalık ile ilgili çalı̧̧maların okullarda uygulamalarının yapılması oldukça günceldir. Bu nedenle bu değişkenle ilgili ilişkisel ve deneysel çalışmaların okullarda farklı yaş, cinsiyet, sosyoekonomik statüden öğrencilerle yapılması önerilmektedir. Öte yandan kaygı konusunda anneleri bilgilendirecek ve ergenlerde bilinçli farkındalık düzeyini arttıracak eğitimler ve seminerler yapılması öğrenciler için yararlı olabilir. Bununla birlikte okullardaki psikolojik danışmanlık ve rehberlik birimlerinde bilinçli farkındalık çalışmalarının arttırılmasının yanı sıra kaygı problemlerine yönelik önleyici ve gelişimsel hizmetler kapsamında uygulanması önerilmektedir. Bunun yanı sıra okullarda düzenlenebilecek seminerler ile annelere kendi kaygı düzeylerinin çocuklarının kaygı düzeyleri üzerindeki etkisi hakkında psikoeğitim verilmesi ve anneler ile bilinçli farkındalık çalışmalarının yürütülmesi ile de halk sağlığına katkı sağlanabilir. 


\section{KAYNAKÇA}

Abac1, R. (1986). Demokratik, otoriter ve ilgisiz olarak algllanan anne-baba tutumlarınin çocuğun kaygı düzeyi ile ilişkisi. Yüksek Lisans Tezi, Ankara Üniversitesi, Sosyal Bilimler Enstitüsü, Ankara.

Alisinanoğlu, F., \& Ulutaş, İ. (2000). Çocuklarda kaygı ve bunu etkileyen etmenler. Milli Ĕ̈itim Dergisi(145), 15-19.

Arslan, I. (2018). Bilinçli farkindalik, depresyon düzeyleri ve algılanan stres arasindaki ilişki. Birey ve Toplum Sosyal Bilimler Dergisi, 8(2), 73-86.

Aydemir, Ö., \& Köroğlu, E. (2000). Psikiyatride kullanılan klinik ölçekler. Hekimler Yayın Birliği, Ankara, 5.

Aydın, D. Y. (2018). Üniversite sınavına hazırlanan ögrencilerin sınav kaygısı, bă̆lanma stilleri ve annelerinin kaygı düzeyleri. Yayınlanmamış Yüksek Lisans Tezi, Hacettepe Üniversitesi, Eğitim Bilimleri Enstitüsü, Ankara.

Baron, R. M., \& Kenny, D. A. (1986). The moderator-mediator variable distinction in socialpsychological research: conceptual, strategic and statistical considerations. Journal of Personality and Social Psychology (51), 1173-1182.

Brown, K. M., \& Ryan, R. (2003). The benefits of being present: mindfulness and its role in psychological well-being. Journal of Personality and Social Psychology( 84(4), 822848.

Bögels, E. I.-B. (2011). The mindful attention awareness scale for adolescents (MAAS-A): Psychometric properties in a Dutch sample. Mindfulness (2), 201-211.

Cesur, G., Sayraç, N. ve Korkmaz, E. (2018). Çocukluk çağı örselenme yaşantıları ve sürekli kaygı arasındaki ilişkide bilinçli farkındalığın rolü. Türk Psikoloji Dergisi, 33(81), 97 112.

Çifter, İ. (1985). Psikiyatri I. Gata Eğitim Yayınları, Ankara, 313-315.

Didonna, F. (2009). Mindfulness and obsessive-compulsive disorder: Developing a way to trust and validate one's internal experience. In clinical handbook of mindfulness (pp. 189219). Springer, New York, NY.

Duman, G. K. (2008). İlköğretim 8. sinıf ögrrencilerinin durumluk sürekli kaygl düzeyleri ile sınav kaygısı düzeyleri ve ana - baba tutumları arasındaki ilişkinin incelenmesi. Yayınlanmamış Yüksek Lisans Tezi, Dokuz Eylül Üniversitesi, Eğitim Bilimleri Enstitüsü, İzmir.

Geçtan, E. (1995). Psikodinamik psikiyatri ve normaldışı davranışlar. (10. Baskı). İstanbul: Remzi Kitabevi.

Hudson, J. L., Dodd, H. F., \& Bovopoulos, N. (2011). Temperament, family environment and anxiety in preschool children. Journal of abnormal child psychology, 39(7), 939-951.

Kabat-Zinn, J., Lipworth, L., \& Burney, R. (1985). The clinical use of mindfulness meditation for the self-regulation of chronic pain. Journal of behavioral medicine, 8(2), 163-190.

Kırık, A. M. (2014). Aile ve çocuk ilişsisinde internetin yeri: Nitel bir araştırma. Ĕgitim ve Ögretim Araştırmaları Dergisi, 3(1).

Kısmetoğlu, G. (2019). 15 - 18 yaş arası ergenlerde duygu düzenleme ve bilinçli farkındalık becerilerinin kaygı düzeyleri ilişkisinin incelenmesi. Yayımlanmamış Yüksek Lisans Tezi, Gelişim Üniversitesi, Sosyal Bilimler Enstitüsü, İstanbul.

Kocaefe, T. (2013). Özerklik veren ebeveynlik stili, bilinçli farkındalık seviyesi ve psikolojik sağllk arasındaki ilişki. Yayınlanmamış Yüksek Lisans Tezi, İstanbul Bilgi Üniversitesi, Sosyal ve Beşeri Bilimler Fakültesi, İstanbul. 
Martini, J., Knappe, S., Beesdo-Baum, K., Lieb, R., \& Wittchen, H. U. (2010). Anxiety disorders before birth and self-perceived distress during pregnancy: associations with maternal depression and obstetric, neonatal and early childhood outcomes. Early human development, 86(5), 305-310.

Mercer, Finucane, A., \& Stewart, W. (2006). An exploratory mixed methods study of the acceptability and effectiveness of mindfulness -based cognitive therapy for patients with active depression and anxiety in primary care. BMC Psychiatry, 6-14.

Messer, S. C., \& Beidel, D. C. (1994). Psychosocial correlates of childhood anxiety disorders. Journal of the American Academy of Child \& Adolescent Psychiatry, 33(7), 975-983.

Öner, N., \& AL, C. (1983). Süreksiz durumluk/sürekli kaygl envanteri el kitabl. 1. Baski. Istanbul: Bogaziçi Üniversitesi Yayınları.

Özusta, Ş. (1995). Çocuklar için durumluk-sürekli kaygı envanterinin uyarlama, geçerlik ve güvenirlik çalışması. Türk Psikoloji Dergisi, 10(34), 32-44.

Roemer, L., Lee, J., Salters-Pedneault, K., Erisman, S., Orsillo, S., \& Mennin, D. (2009). Mindfulness and emotion regulation difficulties in generalized anxiety disorder: Preliminary. Behavior Theraphy, 40(2), 142.

Shapiro, S., Schwartz, G., \& Bonner, G. (1998). Effects of mindfulness-based stress reduction on medical and premedical students. Journal of Behavioral Medicine. 21(6), 581-599.

Shapiro, S. L., Brown, K. W., \& Biegel, G. M. (2007). Teaching self-care to caregivers: Effects of mindfulness-based stress reduction on the mental health of therapists in training. Training and education in professional psychology, 1(2), 105.

Semple, R. J., Lee, J., Rosa, D., \& Miller, L. F. (2010). A randomized trial of mindfulnessbased cognitive therapy for children: Promoting mindful attention to enhance socialemotional resiliency in children. Journal of child and family studies, 19(2), 218-229.

Spielger C.D., Gorsuch, R.I.,\& Lushene, R.E. (1964). The state-trait anxiety inventory (STAI):Test manual for form A. Journal of Nervous and Mental Diesease (136). 124130.

Şahin, N. H., \& Yeniçeri, Z. (2015). "Farkındalık” üzerine üç araç: Psikolojik farkındalık, bütünleyici kendilik farkındalığı ve Toronto bilgece farkındalık ölçekleri. Türk Psikoloji Dergisi, 30(76), 48-64.

Tahiroğlu, A. Y., Avcı, A., \& Çekin, N. (2008). Çocuk istismarı, ruh sağlı̆̆ı ve adli bildirim zorunluluğu. Anadolu Psikiyatri Dergisi (9), 1-7.

Tükel, R. (2000). Anksiyete Bozuklukları. Ankara: Çizgi Tıp.

Ulutaş, İ., \& Alisinanoğlu, F. (2003). Çocukların kaygı düzeyleri île annelerinin kaygı düzeyleri arasındaki ilişkinin incelenmesi. Eğilim ve Bilim, 28(128), 65-71.

Ulutaş, İ., \& Demiriz, S. (2003). 9-12 Yaş çocuklarının kaygı düzeylerinin bazı değişkenlere göre incelenmesi. Ege Eğitim Dergisi, 1-9.

Ülev, E. (2014). Üniversite ögrrencilerinde bilinçli farkındalık düzeyi ile stresle başa çıkma tarzının depresyon, kaygl ve stres belirtileriyle ilişkisi. Yüksek Lisans Tezi, Hacettepe Üniversitesi, Eğitim Bilimleri Enstitüsü, Ankara.

Vøllestad, J., Nielsen, M. B., \& Nielsen, G. H. (2012). Mindfulness-and acceptance-based interventions for anxiety disorders: A systematic review and meta-analysis. British journal of clinical psychology, 51(3), 239-260.

Vøllestad, J., Sivertsen, B., \& Nielsen, G. H. (2011). Mindfulness-based stress reduction for patients with anxiety disorders: Evaluation in a randomized controlled trial. Behaviour research and therapy, 49(4), 281-288. 
Yavuz, M., Çalkan, B., Sönmez, E., Tetik, G., \& Kadak, M. T. (2009). Ergen yaş grubunda bilinçli farkındalık ölçeğinin psikometrik özelliklerinin incelenmesi. Turk $J$ Child Adolesc Ment Health, 26(2), 68-74.

Yavuzer, H. (1994). Çocuk Psikolojisi. İstanbul: Remzi Kitapevi.

Y1ldırım, D. D. (2018, Temmuz 20). 10-14 Yaş Ergenlerin Öz Yeterlik Düzeyinin Anksiyete Duyarlılığl ve Ebeveyn Tutumu ile İlişkisinin İncelenmesi. Yüksek Lisans Tezi, Gelişim Üniversitesi, Sosyal Bilimler Enstitüsü, İstanbul. 